\title{
An Empirical Study on the Relationship of Fiscal Revenue to Welfare Lottery and Non-tax Revenue Based on Co-integration Theory and Vector Error Correction Model
}

\author{
Chen Yu' ${ }^{1}$, Liu Haiying ${ }^{2}$, Xiang $\mathbf{Y i}^{\mathbf{3}}$ \\ 1 School of Public Management, Southwest Jiaotong University, Chengdu, P.R.China, 610031 \\ 2. Law \& Politics School of Ocean University of China, Qingdao, P.R.China, 266100 \\ 3. School of Economics \& Management, Southwest Jiaotong University, Chengdu, P.R.China, \\ 610031 \\ (E-mail: 1554890550@qq.com)
}

\begin{abstract}
The research of welfare lottery and non-tax revenue is not the mainstream in the the public economics research, but lottery public welfare funds in the non-tax revenue have exceeded some regular tax revenue. In this paper, based on Co-integration Theory and Vector Error Correction Model, we use the related data from 1987 to 2011 to do some empirical study for the first time. The empirical results show that there is a long-term balanced relationship among the welfare lottery, non-tax revenue and fiscal revenue, furthermore, the former two have a significantly forward effect on the fiscal revenue. During a short period, welfare lottery revenue Granger causes non-tax revenue; non-tax revenue and welfare lottery revenue have a negative effect on the fiscal revenue. Therefore, the government should strengthen the management of non-tax collection and guide the development of the welfare lottery business to fully play their long-term forward effect.
\end{abstract}

Key words: Welfare Lottery, Non-tax Revenue, Fiscal Revenue, Co-integration, VEC Model

\section{Introduction}

Non-tax revenue is a relatively new concept in China, it has been gradually used in research, social activities and government management areas in recent years.It is a kind of fiscal revenue which developed with social economy development, and it played an important role in the social economy development during its emergence and development process. As a relatively flexible form of government financing, the non-tax revenue could raise a lot of funding for some specific social activities in a short period of time. Non-tax revenue accounted for about $1 / 3$ of total government revenue, it has become an indispensable part of China's fiscal revenue.In 1980 s, with the economic reform, the various government departments and local governments using the non-tax revenue to raise funds, expanding the scale of the non-tax revenue.The drawbacks appear with the expansion of non-tax revenue scale, irregular charge, indiscriminate collection of funds, arbitrary fines and other issues lead to a heavy social burdens to the community, which seriously distorted the normal market economy order.Strengthen the research on government non-tax revenue theory helps establishing the integrity government revenue theory and government financing theory, it has significance to improve china's financial theory system.

Since non-tax revenue raised relatively late comparison of tax, current research is mainly focus on the definition of the concept, the problems of the management system reform and innovation.(Liu HanBo 2008).Cui Zhennan(2003) raised suggestions for the management of lottery funds. Liu Yonghui (2003) elaborated the standardized management of non-tax revenue of the 
government.Bai Yufei(2006) argued that non-tax revenue management should be supplemented by supporting reform measures. GuanYonghao (2007) argued that the lack of effective legislation and supervisory mechanism lead to lack of non-tax revenue management. The general view of the economic impact of non-tax revenue has a positive effect but have a negative impact as well.Chen Peigang (2003) stated that the flexibility of non-tax revenue match the capital needs during Chinese transition process from a planned economy to a market economy.Tian Zhigang (2004) raised point that non-tax revenue has impact to enhance the national macro-control capacity, set up public welfare and to promote local economic development, but in the long run, it has a negative impact on economic growth, which is not conducive to economic development.Pan Mingxin, Kuang Ping (2005) proposed that non-tax revenue has economic rationality of existence in national economic construction, but has some limitations as well. Some scholars gave quantitative analysis of non-tax revenue impact on the economy.Wang Xiaoli (2005) employs an econometric model, draws out that non-tax revenue has no significant economic impact from the perspective of spending, and the substitution effect exist between the non-tax revenue and taxation.

In other countries, since the ratio of non-tax revenue of total fiscal revenue is not high, only few scholars doing research on the non-tax revenue. More importantly, there is no terminology of non-tax revenue in other countries, non-tax revenue just exist as a concept of the fiscal revenue and expenditure, therefore, foreign scholars more focus on the fees and charges. Ichard A. Musgrave (1984)proposed the type of government fees and charges, there are two kinds of government fees and charges: one based on services, the other is a management fee. Raimondo, Henry and John(1992) discussed that the fees and charges levied by the government should consider the impact on economic growth and economic efficiency, and the impact of distribution is also need to be take into account. Harver S. Rosen (2000) and agrees the fees or charges is the price paid by users to enjoy the goods or services provided by the Government. Harvey.S.Rosen(2000) state that the use fee is the price paid by users to enjoy the goods or services provided by the Government. Joseph
E Stiglitz (2005) believes that if exclusiveness exsit, even if the consumption of non-competitive, the government often charge the beneficiaries of the public goods or services, such cost should be user fees. Osbome and Plastrik (2001) believe that user fees is the financial cost charge to the customer by government, the money used to pay all or part of the cost of providing services.

Lottery industry in China is an emerging industry, which played an important role to promote the development of public service and the social welfare. At present, from the respective of the government monopoly lottery operation and promote the development of social welfare, the lottery actually has become an important kind of public financing supplement. Support the development of social security is a crucial issue of the public finance, from the respective of the usage of China's lottery, most of the funds used to replenish the social security fund.

Researches on welfare lottery are few in China because of late start in lottery industry. What's more, specialized researches on relationship between welfare lottery and fiscal revenue are even fewer. Guo Xinwei (2000) made a discussion on welfare of welfare lottery. Cui Zhennan (2003) made corresponding proposals for management of lottery fund. Zhang Zhanbin (2001) explored the relationship between the gaming industry and government option qualitatively from multiple aspects. Sun Kejun (2003) made a qualitative analysis on problems existing in fund management of welfare lottery and made some proposals. Fan Liming (2003) studied the effects of welfare lottery on social economy. Zhang Yawei (2005) made a theoretical analysis on people's gaming behavior from the point of gaming behavior. Wang Wuyi (2005) studied financial issues related to the gaming industry systematically. Li Gang (2006) adapted empirical methods to investigate influential elements on lottery sales. Zhang Xiangda (2006) made an empirical analysis of distribution efficiency of welfare lottery. Sun Huihui (2009) studied the developments of lottery in China from the perspective of welfare fair. Zhang Xinrong, Liu Xiaofang (2011) conducted a research on sources, destinations and management of welfare lottery fund.

Researches on welfare lottery abroad mainly focus on the status of welfare lottery revenue, 
the effects on government's financial system, stability of welfare lottery and the correlation with government's other revenues. Mikesell, Zorn (1988) suggested that lottery revenue in America accounted for less state revenue, but it was on the rise. Mikesell made a comprehensive analysis on effects the lottery played on local fiscal system. Kearney (2002) analyzed the contribution rate each American state made to local government revenue. Mikesell, Zorn (1988) made negative evaluations for lottery and believed that lottery revenue was instable. However, Szakmary, Szakmary (1995) and Tosun, Skidmore (2004) held that lottery revenue was useful owing to the fact that sources of this revenue had nothing to do with other fiscal revenues. Fink, Marco, Rork (2002) suggested that lottery revenue influenced the construction of government's revenue.

From the analysis of documents, it is concluded that the researches on non-tax revenue and welfare lottery abroad and home are qualitative, quantitative researches are few. Moreover, the study on relationship between welfare lottery, non-tax revenue and fiscal revenue is rare. This paper, based on the relevant economic data from 1987 to 2011, makes a quantitative analysis of the relationship between these three factors with co-integration theory and venter error correction model to explore the relationship between welfare lottery, non-tax revenue and fiscal revenue in a good way to increase their positive effect on economy.

\section{Data Sources and Methodology}

\subsection{Data Sources}

In this paper,we examine the relationship among the welfare lottery, non-tax revenue and fiscal revenue for the years 1987-2011. All of the data used in this study are from China Civil Affair' Statistical Yearbook 2011.

\subsection{Co-integration Theory and Vector Error Correction (VEC) Models}

In this paper, we use the co-integration theory and VEC model to analyze the relationship among the welfare lottery, non-tax revenue and fiscal revenue.If the un-stationary variable in the VAR model is co-integrated, we can found a VEC model on the basis of the VAR model.
The mathematical representation of a $\operatorname{VAR}(p)$ is:

$y_{t}=a_{1} y_{t-1}+a_{2} y_{t-2}+\cdots+a_{p} y_{t-p}+B x_{t}+\mathrm{e}_{t}$

where $y_{t}$ is a vector of endogenous variables, is $x_{t}$ a vector of exogenous variables, $a_{1}, \cdots, a_{p}$ and $B$ are matrices of coefficients to be estimated, and $e_{t}$ is a vector of innovations that may be contemporaneously correlated but are uncorrelated with their own lagged values and uncorrelated with all of the right-hand side variables.

A vector error correction (VEC) model is a restricted VAR designed for use with nonstationary series that are known to be co-integrated. The VEC has co-integration relations built into the specification so that it restricts the long-run behavior of the endogenous variables to converge to their co-integrating relationships while allowing for short-run adjustment dynamics. The co-integration term is known as the error correction term since the deviation from long-run equilibrium is corrected gradually through a series of partial short-run adjustments.

To take the simplest possible example, consider a two variable system with one co-integrating equation and no lagged difference terms. The co-integrating equation is:

$$
y_{2, t}=b y_{1, t}
$$

The corresponding VEC model is:

$$
\begin{aligned}
& \mathrm{D} y_{1, t}=a_{1}\left(y_{2, t-1}-b y_{1, t-1}\right)+e_{1, t} \\
& \mathrm{D} y_{2, t}=a_{2}\left(y_{2, t-1}-b y_{1, t-1}\right)+e_{2, t}
\end{aligned}
$$

In this simple model, the only right-hand side variable is the error correction term. In long run equilibrium, this term is zero. However, if $y_{1}$ and $y_{2}$ deviate from the long run equilibrium, the error correction term will be nonzero and each variable adjusts to partially restore the equilibrium relation. The coefficient $a_{i}(i=1,2)$ measures the speed of adjustment of the $i$-th endogenous variable towards the equilibrium.

\subsection{Test Methods}

\subsubsection{Unit Root Test}


A lot of time series are not stationary, and the phenomenon of "spurious regression" may be generated from the regression of the nonstationary series.In order to avoid the phenomenon, it is necessary to sequence the unit root test to determine the stability of the (determine) the sequence before the time of series analysis. There are many methods of unit root tests, in this paper we use the ADF test.And we have chosen to estimate an ADF test that employs maximum lag length selection using a Schwarz Information Criterion.As with the ADF test, We set up a null hypothesis $H_{0}$ : the time series have an unit root. if the statistic value is greater than the critical value, we do not reject the null hypothesis at conventional test sizes comparing the ADF statistic value with the critical value at the a levels. So the original time series is not stationary.

\subsection{2. co-integration Test}

When multiple time-series variables are not stationary, a linear combination of two or more non-stationary series may be If such a stationary linear combination exists, the non-stationary time series are said to be co-integrated. The stationary linear combination is called the co-integrating equation and may be interpreted as a long-run equilibrium relationship among the variables.In this paper, we use the methodology developed in Johansen to carry out the Johansen co-integration test.Johansen co-integration test there are two ways, and we use the max-eigenvalue test methods. Johansen co-integration test is not a completely independent test, but a continuous test of $r=0 \quad$ followed by the next value. And we have also chosen to estimate an Johansen co-integration test that employs maximum lag length selection using a Schwarz Information Criterion. As with Johansen co-integration test, We set up a null hypothesis $H_{0}$ : the time series have $r$ vectors of co-integrating relations. If the statistic value is greater than the critical values, we reject the null at conventional test sizes.

\section{Result}

\subsection{Unit Root Test}

To eliminate the heteroskedasticity in time series, we make the logarithmical of null data and don't change the original co-integrated relation after it, and can even make it Linear trend. Therefore, before analyzing these relations, we use the ADF root test to Take $e$ as the bottom of the logarithm to variables, and then make a stability test to the logarithm variable and their difference series. In this paper, the software Eviews5.0 is used to make the ADF unit test, and the result is followed in Table 1.

From Table 1,we can see that these null series are unstable under a 10\% level of significance, the first differences of null series are stationary at $5 \%$ level, that's to say there exists unit $\mathrm{I}(1)$ in these three original time series variables. Due to the un-stability of the null series, we need to use the co-integration test to Verify whether there is co-integrated relation between each variable.

\begin{tabular}{l|l|l|l|l}
\hline & $\begin{array}{l}\text { ADF test } \\
\text { statistics }\end{array}$ & Critical values & Level & Include in test equation \\
\hline $\ln F$ & -0.856858 & -3.243079 & $10 \%$ & Trend and intercept \\
\hline $\ln L$ & -2.011093 & -2.642242 & $10 \%$ & Trend and intercept \\
\hline $\ln \mathrm{D}$ & -2.406587 & -3.243079 & $10 \%$ & Trend and intercept \\
\hline $\mathrm{D} \ln \mathrm{F}$ & -4.770790 & -4.416345 & $1 \%$ & Trend and intercept \\
\hline $\mathrm{D} \operatorname{lnL}$ & -6.108624 & -4.440739 & $1 \%$ & Trend and intercept \\
\hline $\mathrm{D} \operatorname{lnR}$ & -3.934184 & -3.632896 & $5 \%$ & Trend and intercept \\
\hline
\end{tabular}

\subsection{Johansen co-integration Test}

Make a Johansen co-integrated test to make the logarithmical of data,the result is followed in

Table 2 .From Table 2,we know that, under $5 \%$ level of significance, there exists one co-integrated relation among three variables, namely, a long-term balanced relation exists at $95 \%$ probability among welfare lottery, non-tax revenue and fiscal revenue, the co-integration equation is:

$$
\ln R=0.4559 \ln F+0.3964 \ln L
$$




\begin{tabular}{llllll}
\hline $\begin{array}{l}\text { Hypothesized } \\
\text { CE }(\mathrm{s})\end{array}$ & No. of & Eigenvalue & $\begin{array}{l}\text { Max-Eigen } \\
\text { Statistic }\end{array}$ & $\begin{array}{l}0.05 \\
\text { Value }\end{array}$ & Critical \\
\hline None & & 0.888419 & 43.86017 & 21.13162 & 0.0000 \\
At most 1 & & 0.371694 & 9.294558 & 14.26460 & 0.2625 \\
At most 2 & & 0.137467 & 2.957640 & 3.841466 & 0.0855 \\
\hline
\end{tabular}

Table 2: Johansen co-integration Test

From co-integration equation (3) we can know that, per unit increased in $\mathrm{F}$ will increase 0.4559 unit of the fiscal revenue. per unit increased in L will increase 0.3964 unit of the fiscal revenue. From co-integration equation (3),we can see that both welfare lottery and non-tax revenue has positive effects on fiscal revenue; non-tax revenue is an important part of fiscal revenue, and it is mainly used to satisfy social public needs and quasi-public demand. So, reasonably gathering non-tax revenue can greatly promote the increase of fiscal revenue. Some of the welfare lottery revenue is transformed into tax, however, public welfare fund from it is non-tax revenue, and the amount of the fund has exceeded normal tax category in recent years The fund share a lot of expenditure on social welfare cause, and generate a good social welfare effect, which serves as a good explanation for the positive effect of the welfare lottery revenue. So, attach importance to reasonable non-tax revenue, develop welfare lottery business and properly make use of non-tax revenue will alleviate payment pressure of the revenue and greatly promote the economic prosperity of society. Per unit increased in non-tax revenue will in the long run promote 0.456 unit increase in fiscal revenue.

\subsection{VECM}

After examining the variables have relationship of co-integration, we can construct vector error correction model (VECM) and observe the causal short-term interaction effects and relationship between the variables. The parameters of the VEC model estimated value shown in Table 3.Taking the third column of the table 4 value, we can construct co-integration equation. The co-integration equation is:

$$
\begin{aligned}
\operatorname{Dln} R_{t}= & -0.2093 \mathrm{D} \ln F_{t-1}-0.2289 \mathrm{D} \ln F_{t-2}+0.0366 \mathrm{D} \ln F_{t-3} \\
& -0.1008 \mathrm{D} \ln L_{t-1}-0.0132 \mathrm{D} \ln L_{t-2}-0.0394 \mathrm{D} \ln L_{t-3} \\
& +0.0238 \mathrm{D} \ln R_{t-1}-0.3597 \mathrm{D} \ln R_{t-2}-0.0120 \mathrm{D} \ln R_{t-3} \\
& +0.1188 e c m_{t-1}+0.2916+\mathrm{e}_{t}
\end{aligned}
$$

$\mathrm{AIC}=-3.9432, \quad \mathrm{SC}=-3.3961$.

There ecm is error correction term for short-run equilibrium to long-run equilibrium. We can see that the model overall effect is significant from the AIC value and SC value. From table 4,we can find that the statistical values are significant among $\operatorname{Dln} F_{t-1}, \operatorname{Dln} L_{t-1}, \operatorname{Dln} L_{t-3}$ and Dln $R_{t-2}$, and the others are not significant. In the short term, the current fiscal revenue effect is remarkable because of the impulse coming from $\operatorname{Dln} F_{t-1}$, Dln $L_{t-1}$, Dln $L_{t-3}$, that is negative; But Dln $R_{t-2}$ has positive effect on fiscal revenue, and its effect is not obvious.
From model (4) we see that non-tax revenue in the former period has a relatively great influence on the current fiscal revenue, its elasticity is -0.209 .It shows that if the non-tax revenue in former period increases, the current fiscal revenue will accordingly decrease, mainly because that the non-tax revenue in the former period influences the current non-tax revenue and consequently influences the current fiscal revenue. The public welfare fund of welfare lottery in the former period also greatly affects the current fiscal revenue, its elasticity is -0.101 , the former restrains the latter's increase. This is because the public welfare fund is gathered according to a certain 
rate, and it is mainly used in social welfare cause. The increase of the welfare fund in the former period will increase the non-tax revenue at the same time so that the government reduce the levy of the non-tax revenue, as a result, the current fiscal revenue decreases. Two lag fiscal revenue has a relatively great negative effect on current revenue, its elasticity is -0.36 . its elasticity is -0.36 . It shows that the higher the fiscal revenue in former two periods, the lower it is in the current period。 It restrains the current revenue to some degree. It can be explained that because of the fiscal revenue increase in former two periods, the government is optimistic about the economic prospect in the short future and relax the right supervision over each area so that the current economy can't develop well as expected。

From model (4) we can also see, three lag welfare fund has an positive effect on the current fiscal revenue, but it is relatively small, its elasticity is 0.039 . This is because people are very enthusiastic in the former three periods, directly increasing the whole revenue of the welfare lottery and the welfare fund. But players didn't get satisfying profit directly from welfare lottery, so they reduce or stop their purchase or invest in other risk projects; However, these people can't resist the temptation of grand reward, and buy it again after two periods of consideration, making current welfare lottery revenue and fiscal revenue slightly increase.

In general, from model (4), each variable influences the increase of fiscal revenue through a long-term balanced relation. About $11.88 \%$ deviation between the actual value of each year's fiscal revenue and the long-term equilibrium value is corrected. In lag four terms, welfare lottery can Granger cause non-tax revenue, which means that welfare lottery revenue has a significant promotion to the increase of non-tax revenue. However, from the long-term relationship between non-tax revenue, welfare lottery and fiscal revenue in model (4), we can see that both non-tax revenue (F) and welfare lottery (L) have an positive effect on the increase of fiscal revenue, and cause its increase. Non-tax revenue has a relatively great proportion in fiscal revenue, the ratio is 0.455 , that's to say it is an important part in fiscal revenue.

\begin{tabular}{|c|c|c|c|}
\hline & $\begin{array}{l}-0.7243 \\
(0.0695) \\
\end{array}$ & $\begin{array}{l}-0.8267 \\
(0.2717) \\
\end{array}$ & $\begin{array}{l}-0.2093 \\
(0.0134)\end{array}$ \\
\hline & -0.0322 & -0.7599 & -0.2289 \\
\hline & $(0.9192)$ & $(0.2186)$ & $(0.0653)$ \\
\hline & -0.0713 & -0.2197 & 0.0366 \\
\hline & $(0.8468)$ & $(0.7566)$ & $(0.6331)$ \\
\hline & -0.0390 & -0.7031 & -0.1008 \\
\hline & $(0.8624)$ & $(0.0970)$ & $(0.0371)$ \\
\hline & -0.0877 & -0.6901 & 0.0132 \\
\hline & $(0.6512)$ & $(0.0709)$ & $(0.7425)$ \\
\hline & 0.1011 & 0.0160 & 0.0394 \\
\hline & $(0.2698)$ & $(0.9269)$ & $(0.0426)$ \\
\hline & 0.3373 & -1.7219 & 0.0238 \\
\hline & $(0.7650)$ & $(0.4286)$ & $(0.9189)$ \\
\hline & 0.9175 & 1.8860 & -0.3597 \\
\hline & $(0.2764)$ & $(0.2443)$ & $(0.0444)$ \\
\hline & 0.8973 & -2.1534 & -0.0120 \\
\hline & $(0.4427)$ & $(0.3384)$ & $(0.9603)$ \\
\hline ecm & 0.1188 & 0.0893 & 0.0628 \\
\hline & $(0.1592)$ & $(0.5758)$ & $(0.0009)$ \\
\hline $\mathrm{C}$ & -0.0856 & 1.1864 & 0.2916 \\
\hline & $(0.8480)$ & $(0.1729)$ & $(0.0034)$ \\
\hline R-squared & 0.6243 & 0.7182 & 0.8083 \\
\hline $\mathrm{AIC}$ & -0.7942 & 0.5094 & -3.9432 \\
\hline $\mathrm{SC}$ & -0.2470 & 1.0565 & -3.3961 \\
\hline
\end{tabular}

Table 3: Vector Error Correction Estimates

Note: each number in parentheses is probability value 
Compared with non-tax revenue, the proportion of the welfare fund is relatively small, but its ratio is 0.369 which is also great. Above all, welfare lottery can greatly boost the increase of fiscal revenue, and it deserves attentions from all aspects.

\section{Conclusion}

According to above analysis and the result in co-integration equation ( 3 ) and VECM (4),we can conclude that. The time series in non-tax revenue, pubic welfare fund of welfare lottery and fiscal revenue are unstable, but their first difference is stable, There is a long-term balanced relation among them and the variables can affact each other through this relation. In short term, pubic welfare fund of welfare lottery Granger causes non-tax revenue. At the same time, during a short period, have a significantly negative effect on current fiscal revenue, and also restrain it . During a long period, non-tax revenue has a significantly positive promotion to fiscal revenue, and takes up a large part in fiscal revenue. the policy can be reflected in two aspects, while we notice contributions that tax revenue makes to the fiscal revenue, we should also attach great importance to the contributions that non-tax revenue makes and the healthy and fast development of the welfare lottery business. So that more funds can be raised for the social and welfare services to reduce financial burden and promote harmony development of our society.

Acknowledgment: The research work is financially supported by the Ministry of Education, Humanities and Social Sciences Youth Fund of China (11YJC790102).

\section{References}

[1] Nie Shaolin. A Study on Non-tax Revenue Management Innovation for Local Government[D].

Liaoning: Dongbei University of Finance and Economics, 2011:19-20.(In Chinese)

[2] Richard A. Musgrave. Public Finance in Theory and Practice[M]. Beijing: China Financial and Economic Publishing House, 1984:86-103. (In Chinese)

[3] Harver S. Rosen . Public Finance[M]. Beijing : China Renmin University Press,
2000:118-141. (In Chinese)

[4] Joseph E. Stiglitz. Economics[M]. Beijing : China Renmin University Press, 2005:95-121. (In Chinese)

[5] Davicl Osborne, Peter Plastrik. Banishing Bureaucracy[M]. Beijing: China Renmin University Press, 2001:178-191. (In Chinese)

[6] Liu Yonghui. Perfect the Government Functions and Strengthen the Management of Non-tax Revenue[J]. Jiangxi Finance Tax and Accounting, 2003(S1):51-52. (In Chinese)

[7] Bai Yufei. The study of Chinese Government Non-tax Revenue[M]. Beijing: Economic Science Press, 2008:127-134 . (In Chinese)

[8] Guan Yonghao. The Anomie Phenomenon and Standard Management of Government Non-tax Revenue[J]. Northern Economy, 2007(21):66-67. (In Chinese)

[9] Pan Mingxin, Kuang Ping. The Study about the Innovation of the Government Manage Mode of Non-tax Revenue[J]. Chinese Public Administration, 2005(2):39-42. (In Chinese)

[10] Wang Xiaoli. An Empirical Analysis of the Long Run Effect of Public Expenditure on Economic Growth[J]. Journal of Finance and Economics, 2005(4):122-132. (In Chinese)

[11] Mikesell John L, Zorn Kurt. State Lotteries for Public Revenue[J]. Public Budgeting \& Finance, 1988 (4):38 - 47.

[12] Mikesell John. Lotteries in the State Fiscal System[J]. Journal of Gambling Studies, 1990,6(4): 313-330.

[13] Szakmary Andrew C, Szakmary Carol Matheny. State Lotteries as a Source of Revenue: A re-examination[J]. Southern Economic Journal, 1995 61(4): 1167 1181.

[14] Tosun Mehmet Serkan, Skidmore Mark. Interstate Competition and State Lottery Revenues[J]. National Tax Journal, 2004,57(2):163 - 178.

[15] Fink Stephen C, Marco Alan C, Rork Jonathan C. The Impact of State Lotteries on State Tax Revenues [ J ]. National Tax Association -Tax Institute of America, Proceedings of the Annual, 2002: 391 395.

[16] Guo Xinwei. Welfare lottery is "welfare" or not[J]. Economist, 2001(1):118-119. (In 
Chinese)

[17] Cui Zhennan. Research on Lottery Management and Gambling Exploration in China[D].Tianjin: Tianjin University, 2003:52-76. (In Chinese)

[18] Zhang Zhanbin. Commercial Gaming and Government Options[D]. Beijing: Party School of the Central Committee of CPC, 2001:164-181. (In Chinese)

[19] Sun Kejun, $\mathrm{Mu}$ Chenggang. The Problems and Countermeasures of Welfare lottery Fund Manage- ment[J]. China Audit, 2003(4):44-45. (In Chinese)

[20] [20] Fan Liming, Shi Shaogang. Empirical Analysis on Voluntary Provision of Public Goods in China-From the View of China $[\mathrm{J}]$. Contemporary Finance \& Economics, 2003(10):25-29. (In Chinese)

[21] Zhang Yawei. Lottery Behavior: A Theoretical Framework and Economics Analysis[D]. Suzhou: Soochow University, 2006:92-121. (In Chinese)

[22] Wang Wuyi. The World Gambling Explosion and Chinese Economic Benefit[M].Beijing: Economic Science Press, 2005:305-378. (In Chinese)

[23] Li Gang. The Study on the Development of Lottery Industry Based an Empirical Analysis of the Current Situation[D]. ShangHai: Fudan University, 2006:115-127. (In Chinese)

[24] Zhang Xiangda, Zhang Ming. The Study about the Lottery Effect Based on an Empirical Analysis on Economy System Frame[J]. Contemporary Finance \& Economics, 2006(12):14-19.(In Chinese)

[25] Sun Huihui, Xin Suyuan. The Study about the Development of Lottery Industry Based on the Perspective of Welfare Fair[J]. Productivity Research, 2009(23):123-124. (In Chinese)

[26] Zhang Xinrong, Liu Xiaofang. The Study of Lottery Public Welfare Fund Based on the Perspective of Welfare Fair[J]. Enterprise Economy, 2011(10):158-160.(In Chinese) 